\title{
Facilitating cross-border real estate transactions in Europe
}

Citation for published version (APA):

Zimmermann, K. (2021). Facilitating cross-border real estate transactions in Europe: An exploration.

[Doctoral Thesis, Maastricht University]. Maastricht University. https://doi.org/10.26481/dis.20210602kz

Document status and date:

Published: 01/01/2021

DOI:

10.26481/dis.20210602kz

Document Version:

Publisher's PDF, also known as Version of record

\section{Please check the document version of this publication:}

- A submitted manuscript is the version of the article upon submission and before peer-review. There can be important differences between the submitted version and the official published version of record.

People interested in the research are advised to contact the author for the final version of the publication, or visit the DOI to the publisher's website.

- The final author version and the galley proof are versions of the publication after peer review.

- The final published version features the final layout of the paper including the volume, issue and page numbers.

Link to publication

\footnotetext{
General rights rights.

- You may freely distribute the URL identifying the publication in the public portal. please follow below link for the End User Agreement:

www.umlib.nl/taverne-license

Take down policy

If you believe that this document breaches copyright please contact us at:

repository@maastrichtuniversity.nl

providing details and we will investigate your claim.
}

Copyright and moral rights for the publications made accessible in the public portal are retained by the authors and/or other copyright owners and it is a condition of accessing publications that users recognise and abide by the legal requirements associated with these

- Users may download and print one copy of any publication from the public portal for the purpose of private study or research.

- You may not further distribute the material or use it for any profit-making activity or commercial gain

If the publication is distributed under the terms of Article $25 \mathrm{fa}$ of the Dutch Copyright Act, indicated by the "Taverne" license above, 


\section{Summary}

European cross-border real estate transactions occur when European citizens either acquire a plot of land that is located in a different Member State or when they buy it from a seller, who is a resident of a foreign Member State. When such a cross-border element is added to the transaction, the complexity that coins purely national real estate transactions significantly increases. An additional factor is that statistics suggest that the occurrence of cross-border real estate transactions will keep increasing as European citizens exercise their free movement rights to acquire real estate as a primary or secondary residence or as a buy-to-let investment. In view of this development, it is considered desirable to reduce the complexity of such cross-border transactions to strengthen the proper functioning of the EU internal market. To this end, this doctoral thesis proposes different strategies through which such a reduction can be achieved.

The formulation of these strategies was preceded by systematic groundwork. First, in order to gain an in-depth understanding of national land registration systems, the land registration systems of the Netherlands, Germany, and England \& Wales were studied through a theoretical and practical lens. This revealed that the observed divergences are not exclusively the result of the civil law common law divide; fundamental differences exist even within the group of continental Napoleonic systems, especially when positive and negative land registration systems are being compared. This provides for the fact that for instance the German system in certain aspects, such as the mandatory involvement of a Latin notary, shows greater similarity to the Dutch system, while in other aspects, such as the legal value of land register information, more parallels can be found with the system of England \& Wales, given that both are positive registration systems. Other important factors that contribute to divergences are the degree of centralization of land registries and cadastral organizations as well as the achieved level of digitalization of land registration processes.

This comparative exercise enabled the distillation of the challenges that are faced by the various stakeholders in a cross-border real estate transaction. They are either of an administrative, cultural, legal, or technological nature. Subsequently, it was determined whether these challenges also occur in a purely national real estate transaction, and, if that was the case, whether these challenges have a stronger impact in a cross-border setting. The result was that only nine of the 29 challenges that were identified exclusively occurred in the context of a cross-border real estate transaction. 
However, it was also found that 15 out of the 20 challenges that occur in both a national and a cross-border transaction have a stronger impact in a cross-border setting.

Afterwards, a thorough analysis of the existing European and international initiatives that aim to contribute the facilitation of such transactions followed. Three discoveries were particularly remarkable. First, the number of relevant initiatives was considerably higher than initially expected. Second, the oldest initiative was founded almost 100 years ago. Third, in the majority of cases, the initiators were legal professionals rather than the EU, political institutions or academics. The contribution of these initiatives was then compared to the list of identified challenges so that it could be assessed which challenges still deserve attention. It was concluded that only four challenges are fully resolved through already existing initiatives. These challenges have in common that they fall in the category of administrative challenges. An additional six challenges have not been addressed at all by these initiatives. All other challenges were at least partially addressed.

Based on this analysis, different strategies for the further reduction of these challenges were evaluated. Through the creation of a centralized European Cadastral Authority and Land Registry ("EUCALARY") in combination with the adoption of a uniform set of rules governing the registration of rights and facts and the adoption of a uniform property law, virtually all challenges can be addressed. However, given its highly intrusive nature, it is dismissed as a proportionate strategy to facilitate cross-border real estate transactions. Instead, less invasive strategies for the reduction of the administrative, cultural, legal, and technological challenges were considered. 